Iwona Wrońska

University of Białystok

wronska@uwb.edu.pl

\title{
Procedure of Appointing Members of the European Committee for the Prevention of Torture And Inhuman or Degrading Treatment or Punishment
}

\begin{abstract}
The European Committee for the Prevention of Torture and Inhuman or Degrading Treatment or Punishment (CPT) examines, through visits, the treatment of persons deprived of their liberty (Article 1 of the European Convention for the Prevention of Torture, 1987). CPT activity is based on two principles - cooperation and confidentiality. There are two types of visits, periodic visits and ad hoc visits. Without doubt, the CPT is one of the most important monitoring bodies in the area of interest of the Council of Europe. Due to the specific nature of its work it is worth to look at the members forming the Committee, as well as the legal rules of their appointment, the more so that these issues are not the subject of numerous studies in the doctrine, but are, however, important to the quality of the practical connotations of the operation of international law. The purpose of this discussion is to present the essence of $\mathrm{CPT}$, the specific nature of its composition and the rules for appointing members, both at the national procedure (i.e. pre-selection), as well as on the international stage of the contest.

Keywords: European Committee for the Prevention of Torture, human rights, international organizations

Słowa kluczowe: "Europejski Komitet Zapobiegania Torturom", prawa człowieka, organizacje międzynarodowe

The activity of The European Committee for the Prevention of Torture and Inhuman or Degrading Treatment or Punishment, for more than 25 years, has been a regular element of the European human rights protection mechanism of the Council of Europe ${ }^{1}$. It is considered to be, besides the European Court of Human Rights, the most important international body monitoring compliance with the rights of an individual on the European continent. This is due to the fact that it upholds the prohibition of torture and inhuman or degrading treatment or punishment, which
\end{abstract}

1 More on the issue e.g.: B. Filipek, Kontrola przez Radę Europy wykonywania zobowiązań przyjętych przez państwa członkowskie, Kraków 2007, the unpublished doctoral dissertation. 
today, as shown by the case law of the European Court of Human Rights, is quite frequently violated by the countries. Hence the important role of the body under discussion. Because of the uniqueness of its work, it is worth to take a look at the characteristics of the composition of the Committee and the rules of its appointment. The issue of the procedure for the appointment of its members is not a subject of numerous studies in the doctrine. However, it has important practical connotations, both at the level of practice of the countries and the bodies of the Council of Europe choosing members of the Committee, as well as with regard to the quality of their work. The aim of these considerations is to analyze the functioning of the European Committee for the Prevention of Torture and Inhuman or Degrading Treatment or Punishment in the specifics of its composition and the rules for appointing members, both at the stage of the national procedure (so-called pre-selection) and at the stage of international competitive procedure.

\section{The specificity of the international human rights monitoring bodies}

International agreements do not provide for a uniform standard of operation and organization of international control in respect of compliance with human rights by states. In accordance with the principle adopted in international relations that an international agreement depends on the consensus of the parties, functioning of the treaty instruments control in the agreement is optional. When analyzing treaty provisions, it may be noted that arrangements for establishing mechanisms in monitoring human rights and international human rights control bodies? fall into three groups: a) international agreements that do not provide for any control procedure; b) international agreements, which do not provide for any control procedure, but their implementation - to varying degrees - may be controlled by international bodies within a wider system existing in individual international organizations, for example in the system of the Council of Europe or the UN; c) international agreements containing special inspection procedures and/or international bodies monitoring compliance with human rights.

Treaties that provide for legal instruments for the protection of individual rights, provide for specific measures to control the observance of human rights: reports (preliminary, periodic) ${ }^{2}$, individual complaints and inter-state complaints ${ }^{3}$,

2 See more: R. M. M. Wallace, International Law, FifthEdition, London 2005, pp. 236-238.

3 A complaint can be brought against a state or international organizations/bodies. A state's complaint against another state is called an interstate complaint. A complaint brought by individual or a group of individuals is called an individual complaint. See more: K. Łasak, Warunki dopuszczalności skargi zbiorowej w systemie Europejskiej Karty Społecznej, (in:) Polska i Rada Europy 1990-2005, H. Machińska (ed.), Warszawa 2005, p. 237. Examples of regulations providing for a system of individual complaint (also an interstate complaint) considered by judicial bodies are: European Convention for the Protection of Human Rights and Fundamental 
Procedure of Appointing Members of the European Committee for the Prevention...

visitations (so-called on-the-spot tests) ${ }^{4}$ and petitions ${ }^{5}$. The indicated catalog of legal instruments occurs in the treaties in different ways: it can be limited to only one instrument for instance to the visitation, as in the case of the European Convention for the Prevention of Torture and Inhuman or Degrading Treatment or Punishment (1987), or refer to a few of the measures, e.g. reports and complaints, as in the case of the International Covenant on Civil and Political Rights $(1966)^{6}$.

In the framework of international procedures, international bodies performing control functions can be classified in several categories.

In terms of the rules of creation, international institutions for the protection of human rights can be divided into ${ }^{7}$ :

- created by organs of international governmental organizations based on their resolutions, e.g. International Criminal Tribunal for the former Yugoslavia or Commissioner for Human Rights of Council of Europe;

- international treaty bodies, i.e. acting on the basis of the records of the treaty (also known as treaty bodies), these are the bodies specialized in the protection of a specific category of rights and freedoms (in accordance with the subject of the treaty). Most often they operate under the system of international governmental organizations, not constituting their statutory bodies, but they use the administrative, financial and organizational facilities of the entity in which they operate, e.g. The European Court of Human Rights operating in the system of the Council of Europe.

- statutory organs of international governmental organizations which while performing functions related to the management of the organization, also conduct, as a guardian of statutory objectives, control functions in the field

Freedoms of1950 (Dz.U. z 1993 r. Nr 61, poz. 284) [Journal of Laws of 1993 No. 61 item 284], Inter-American Convention on Human Rights of 1969(with a functioning Inter-American Court of Human Rights) or African Charter on Human and Peoples' Rights of 1981 (with jurisdiction of the African Court on Human and Peoples' Rights).

4 An example of a treaty providing for a form of visitation is the European Convention for the Prevention of Torture nad Inhuman or Degrading Treatment or Punishment of 1987, http:// conventions.coe.int/Treaty/en/Treaties/ Html/126.htm (accessed on: 27.01.2015). See more: R. Kuźniar, Prawa człowieka. Prawo, instytucje, stosunki międzynarodowe, Warszawa 2004, pp. 189-190.

5 Petitions are appeals addressed to an international body, in which a natural or legal person, usually directly concerned, points to infringement of the relevant international agreement. The petition, in its essence is similar to a complaint, is considered by international bodies. This instrument was applied in the European Union legislation. See more: G. Michałowska, Ochrona praw człowieka w Radzie Europy i w Unii Europejskiej, Warszawa 2007, pp. 246-247.

6 International Covenant on Civil and Political Rightsof 1966 (Dz.U. z 1977 r. Nr 38, poz. 167) [Journal of Laws of 1977 No. 38 item 167].

7 A. Bisztyga, Ochrona praw człowieka w systemie Rady Europy, (in:) B. Banaszak, A. Bisztyga (eds.), System ochrony praw człowieka, Kraków 2003, pp. 115-152. 
of human rights observance by member states, e.g. Committee of Ministers of the Council of Europe.

The next division is the distinction of the international control bodies of human rights due to the nature and specificity of the decision-making activities:

a) Judicial authorities - they play the judiciary role in the system of international law, they settle disputes regarding violations of the rights of a human being in a typical procedure of court proceedings. They act under the laws of the treaty or on the basis of the resolutions of international bodies of international governmental organizations.

b) Extrajudicial authorities - usually committees and commissions, or oneman committees, elected for the defined terms of office, in a numerically determined composition. Non-judicial authorities use different (occurring together or individually) control measures, inspired by confidential negotiations, provide good service, formulate recommendations etc. The specificity of the activity of non-judicial authorities consists in making decision, which, however, are different in the means of conditions and with different legal effects than international court judgments. They act according to the treaty law or on the basis of the resolutions of international bodies of international governmental organizations.

In addition, considering the composition criterion (number of members) of international control bodies of human rights, it is still possible to differentiate them into: collective bodies and single-person bodies, which may also function either under the treaty or on the basis of the above-mentioned resolutions of organs of government organizations.

It is also worth paying attention to another possible division of international control bodies of human rights, namely their distinction due to their functions: control (monitoring body) and creating standards of observing human rights (standard-setting body). This distinction appears to be quite theoretical, because contemporary international control bodies of human rights, to a lesser or larger extent, while exercising control functions, naturally play also a creative role as regards the standards of observing human rights.

\section{Origins and the specificity of the European Committee} for the Prevention of Torture and Inhuman or Degrading Treatment or Punishment

The European Committee for the Prevention of Torture and Inhuman or Degrading Treatment or Punishment (hereinafter refferedto as: Committee or CPT) was established under the Article 1 of the European Convention for the Prevention of 
Torture and Inhuman or Degrading. Treatment or Punishment (hereinafter referred to as: ECPT or the Convention against Torture), adopted by the Council of Europe ${ }^{8}$. The Convention was opened for signature by the member states of the Council of Europe on November 26th, 1987. It was entered into force on February 1st, 1989, after the ratification of 7 countries. By 1st of January, 1991, 20 out of 24 member states of the Council of Europe ratified the Convention, and and currently 47 countries are its parties ${ }^{9}$. The Committee started its operations in November 1989, and on 16th of November 1989, and adopted its rules of procedure, so-called Procedural rules ${ }^{10}$.

ECPT does not contain a new catalog of rights and freedoms, but instead it establishes a control mechanism aimed at monitoring the implementation by member states of the Article 3 the European Convention on Human Rights signed in 1950 (hereinafter referred to as the ECHR) ${ }^{11}$, which prohibits torture ${ }^{12}$. The Convention against Torture was concluded in the belief that 'the protection of persons deprived of their liberty against torture and inhuman or degrading treatment or punishment could be strengthened by non-judicial means of a preventive character based on visits' $^{13}$.The first list of countries to conduct the visit in (in 1990), was established by the drawing of lots. It included: Austria, Denmark, Turkey, Malta and the United Kingdom ${ }^{14}$. The first country which was visited by the Committee was Austria.

Although the ECPT directly refers to the provisions of the ECHR control mechanism, i.e. European Court of Human Rights (hereinafter referred to as the Court), the key differences between the specificity of the activities of the CPT and the Court should be pointed out.

8 European Convention for the Prevention of Torture and Inhuman or Degrading Treatment or Punishment, done in Strasbourg on 26 November 1987 (Dz.U. z 1995 r., Nr 46, poz. 238) [Journal of Laws of 1995 No. 46 item 238].

9 http://conventions.coe.int/Treaty/Commun/ChercheSig.asp?NT=126\&CM=1\&DF=\&CL=ENG (accessed on: 27.01.2015).

10 European Committee for the Prevention of Torture and Inhuman or Degrading Treatment or Punishment (CPT). Rules of Procedure, (Adoptedon 16 November 1989 andamended on 8 March 1990, 11 May 1990, 9 November 1990, 31 January 1991, 20 September 1991, 12 March 1997 and 7 March 2008) CPT/Inf/C(2008)1, Strasbourg.

11 Convention for the Protection of Human Rights and Fundamental Freedoms, done in Rome on 4 November 1950 (Dz.U. z 1993 r. Nr 61, poz. 284) [Journal of Laws of 1993 No. 61 item 284].

12 See more: K. Ginther, The European Convention for the Prevention of Torture and Inhuman or Degrading Tre- atment or Punishment, 'European Journal of International Law' 1990, vol. 2, No. 123; H. Haug, Efforts to Eliminate Torture through International Law, 'The International Review of the Red Cross' 1989, No. 775, pp. 9-27.

13 Preamble paragraph 5 of the European Convention for the Prevention of Torture and Inhuman or Degrading Treatment or Punishment of 26 November 1987, op. cit.

14 The European Committee for the Prevention of Torture and Inhuman or Degrading Treatment or Punishment,1st General Report on the CPT's activities covering the period November 1989 to December 1990, CPT/Inf (91)3 - Appendix 3, Strasbourg 1991, p. 1. 
Firstly, the main objective of the Court is to determine whether a breach of the ECHR occurred. While the task of the CPT is to prevent physical or mental abuse of persons deprived of liberty ${ }^{15}$.

Secondly, the Court is bound by the treaty provisions of the ECHR about the standards of human rights and freedoms. CPT is not bound by the provisions of specific international agreements, although it may refer to several treaties and other international instruments and the case law formulated on this basis.

Thirdly, the Court consists of professional lawyers specializing in the field of human rights. CPT consists not only of such lawyers, but also doctors, experts in criminal matters, criminologists, etc.

Fourth, the Court exercises its jurisdiction only after the complaint an individual or inter-state complaints (so-called complaints procedure). CPT performs its functions ex officio as to the periodic or ad hoc visits.

Fifth, the proceedings before the Court end with issuance of legally binding judgment, which states whether there was an infringement of the provisions of the ECHR or not. Whereas the result of the activities of the CPT is the development of the reportof the conducted visit and, if necessary, recommendations on the activities of the member states to correct the abuses of the prohibition of torture and inhuman or degrading treatment or punishment ${ }^{16}$. In case of refusal of the member state with regards to the compliance with the recommendations, the CPT may make a public statement on the matter.

The CPT is an international non-judicialary body of a collegial nature, which operates on the basis of the treaty and, like the ECHR, is not a part of the statutory institutions of the Council of Europe, and functions within the so-called system of the Council of Europe. CPT is not an investigative authority, but it ensures extrajudicial preventive mechanism in order to protect persons deprived of their liberty against torture and other forms of ill-treatment ${ }^{17}$. Therefore it complements the judicial activities of the European Court of Human Rights. It is undisputed that the Court is the most important body established in order to control the observance by member states of the prohibitions arising out of the provision of Article 3 of the

15 The European Committee for the Prevention of Torture And Inhuman or Degrading Treatment or Punishment, 1st General Report on the CPT's activities covering the period November 1989 to December 1990, CPT/Inf (91) 3, Strasbourg 1991, pt 1; The European Committee for the Prevention of Torture and Inhuman or Degrading Treatment or Punishment, Report to the Austrian Government on the visit to Austria carried out by the European Committee for the Prevention of Torture And Inhuman or Degrading Treatment or Punishment (CPT) from 20 May 1990 To 27 May 1990, CPT/Inf(91)11, Strasbourg 1991, p.10.

16 A. Cassese, A New Approach to Human Rights: The European Convention for the Prevention of Torture, 'American Journal of International Law' 1989, No. 83, pp. 128-153.

17 The European Committee for the Prevention of Torture and Inhuman or Degrading Treatment or Punishment (CPT), CPT standards, CPT/Inf/E (2002)1 - Rev.2013, Council of Europe, Strasbourg 2013, p. 4. 
Procedure of Appointing Members of the European Committee for the Prevention...

$\mathrm{ECHR}^{18}$. However, the other body which aims at such control is the Committe, with its preventive instruments ${ }^{19}$.

Control of compliance with the statutory requirements of the ECPT by CPT consists primarily in carrying out the periodic and ad hoc visits ${ }^{20}$, in the places which are particularly vulnerable to the possibility of ill-treatment of people (prisons, juvenile detention centers, police stations, centers for detained immigrants as well as psychiatric hospitals and nursing homes). In addition, an important aspect of the work of CPT is to maintain so-called permanent dialogue with the member states, that is, recurring reports of CPT and members' answers ${ }^{21}$.

\section{The procedure of appointing members of the CPT}

CPT is composed of representatives of the member states of the Council of Europe which are parties to the ECPT. The members of the Committee represent diverse expert environments. They are independent and impartial experts with diverse backgrounds, including lawyers, doctors and specialists in the field of prison system or police ('The Committee members are chosen from among persons of high moral character, known for their competence in the field of human rights or having professional experience in the areas covered by this Convention') ${ }^{22}$. The members of the Committee shall be elected for a period of four years, with the possibility of being re-elected twice. Members of the CPT are acting on their own behalf (i.e., do not represent the country on behalf of which they are delegated) ${ }^{23}$. In order to fully guarantee independence, they do not visit the countries from which they were appointed.

18 Z. Hołda, Europejski Komitet Zapobiegania Torturom (z problematyki instytucji kontrolnych w obszarze Rady Europy), "Annales Universitatis Mariae Curie-Sklodowska' 2008, vol. XV, No. 2 , p. 49.

19 At the same time, it is worth remembering that, especially after 2000, Tribunal has very often referred to the Committees visitation reports as a material helpful in the findings of fact. The case-law of the European Court on Human Rights, under provision of Article 3 of the European Convention on Human Rights is particularly wide, Z. Hołda, Europejski Komitet Zapobiegania Torturom..., op. cit.

20 The European Committee for the Prevention of Torture and Inhuman or Degrading Treatment or Punishment (CPT), The CPT standards 'Substantive' sections of the CPT's General Reports, CPT/ Inf/E(2002)1 - Rev. 2006, Council of Europe, Starsbourg 2006, p. 4.

21 The European Committee for the Prevention of Torture and Inhuman or Degrading Treatment or Punishment, Historical background and main features of the Convention, CPT/Inf. (90)3, Strasbourg 1990, p. 3.

22 Article 4 of the European Convention for the Prevention of Torture and Inhuman or Degrading Treatment or Punishment, done in Strasbourg on 26 November 1987 (Dz.U. z 1995 r. Nr 46, poz. 238) [Journal of Laws of 1995 No. 46 item 238). Ibidem. 
The selection procedure of the Committee members is regulated in ECPT and is two-staged. The first stage is the national proceedings - competition followed by the candidates applying by the state to the Council of Europe, the second stage is the election of a member to the CPT by the Committee of Ministers of the Council of Europe, with the participation of the Parliamentary Assembly of the Council of Europe (hereinafter referred to as PACE) ${ }^{24}$.

\subsection{National procedure}

In Poland, the recruitment of candidates for membership to the CPT is within the competence of the Minister of Justice, who announces the recruitment most often in advance, before the mandate of the representative from Poland expires (usually it is one year $)^{25}$. The current term of office of the Polish representative in the CPT expired on 19 December $2015^{26}$. The Minister of Justice decided to initiate the selection procedure of candidates already in the autumn of 2014, setting the deadline for submitting entries to the 18 December 2014 ('The Minister of Justice announces that due to the expiration of the term of office of a member of the European Committee for the Prevention of Torture on behalf of Poland and in accordance with the provisions of the European Convention for the Prevention of Torture and Inhuman or Degrading Treatment or Punishment and the Resolution 1540 (2007) of the Parliamentary Assembly of the Council of Europe, which regulate the matter of choosing a CPT member, the Minister of Justice decided to start the procedure for selecting candidates for the CPT member on behalf of Poland') ${ }^{27}$.

Candidate applications together with a CV and documents confirming relevant qualifications shall be sent to the Department of International Cooperation and Human Rights of the Ministry of Justice (hereinafter referred to as: MoJ).

According to the MoJ, a CPT candidate should meet the following requirements that are subject to the provisions of ECPT i.e. have a high moral qualifications and professional qualifications as well as experience in the field covered by the mandate of the CPT and have fluent command of English or French (the official languages

24 Article 5 of the European Convention for the Prevention of Torture and Inhuman or Degrading Treatment or Punishment, done in Strasbourg on 26 November 1987 (Dz.U. z 1995 r. Nr 46, poz. 238) [Journal of Laws of 1995 No 46 item 238).

25 In other countries of the Council of Europe, procedures of appointing candidates as CPT members are similar. See e.g.: in Ireland, where a competitive procedure at a national level is conducted by the Ministry of Justice and Equality, http://www.justice.ie/en/JELR/ADVERTISEMENT\%20 English\%20-\%20CPT\%20Nomination.pdf/Files/ADVERTISEMENT\%20English\%20-\%20 CPT\%20Nomination.pdf (accessed on: 28.01.2015).

26 The term of office of a Committee's member from Poland started on 20 December 2015 and will last four years.

27 http://webcache.googleusercontent.com/search?q=cache:GhRqtJAIcGQJ:bip.ms.gov. $\mathrm{pl} / \mathrm{pl} /$ ogloszenia/new-s, 6605, ogloszenie-o-naborze-na-czlonka-europejskiego. $\mathrm{html}+\& \mathrm{~cd}=1 \& \mathrm{hl}=\mathrm{pl} \& \mathrm{ct}=\mathrm{clnk} \& \mathrm{gl}=\mathrm{pl} \& \mathrm{client}=$ firefox-a $($ accessed on: 27.01 .2015$)$. 
of theCouncil of Europe, including also CPT) ${ }^{28}$. In addition, a person should be available in terms of time and profession, in a state of health that ensures the ability to effectively carry out the tasks of a CPT member, because this activity relies largely on monitoring visits in other countries ${ }^{29}$, which last a dozen or so days and take place several times a year.

National procedure, so-called pre-selection, is conducted by means of a competitive procedure, during which three candidates for a CPT member on behalf of Poland are selected from among those nominated. The final election of a representative from the list of three persons indicated by $\mathrm{MoJ}$ is made by the Committee of Ministers of the Council of Europe.

\subsection{International procedure}

The election of CPT members in the Council of Europe takes place in accordance with the provisions of the ECPT and refining Resolution 1540 (2007) of the Parliamentary Assembly of the Council of Europe ${ }^{30}$. The Committee of Ministers of the Council of Europe selects a member to the CPT from the list of three candidates presented by a country. This follows the recommendation of the PACE Bureau ${ }^{31}$, which previously forwards a list of candidates for consideration and opinion of the SubCommittee on Human Rights of the PACE Committee on Legal and Human Rights.

The 2007 resolution is the last regulation of the Council of Europe regarding the appointment of members of the CPT. Previously in this regard the following documents of the PACE were binding: Recommendation $1257(1995)^{32}$ ,Recommendation 1323 (1997) ${ }^{33}$ and Resolution $1248(2001)^{34}$.

28 Roule 12, European Committee for the Prevention of Torture and Inhuman or Degrading Treatment or Punish- ment (CPT), Rules of Procedure, (Adopted on 16 November 1989 and amended on 8 March 1990, 11 May 1990, 9 November 1990, 31 January 1991, 20 September 1991, 12 March 1997 and 7 March 2008) CPT/Inf/C(2008)1, Strasbourg, p. 8.

29 Ibidem.

30 Parliamentary Assembly, Resolution 1540(2007) Improving selection procedures for CPT members, http://as-sembly.coe.int/Main.asp?link=/Documents/AdoptedText/ta07/ERES1540. htm (accessed on: 26.01.2015).

31 The Bureau of the CEPA shall consist of the President of the Assembly, her or his 20 deputies and the chairpersons of five largest political groups, Parliamentary Assembly, Resolution 1379 (2004) Composition of the Bureau of the Assembly, http://assembly.coe.int/nw/xml/XRef/X2H-XrefViewPDF.asp?FileID=17224\&lang=en (accessed on: 26.01.2015).

32 Parliamentary Assembly, Recommendation 1257 (1995) on the conditions of detention in Council of Europe member states, http://www.assembly.coe.int//Main.asp?link=http://www.assembly.coe. int/Documents/AdoptedText/TA95/EREC1257.HTM (accessed on: 25.01.2015).

33 Parliamentary Assembly, Recommendation 1323 (1997) on strengthening the machinery of the European Co- nvention for the Prevention of Torture and Inhuman or Degrading Treatment or Punishment, http://www.assembly. coe.int/Main.asp?link=/Documents/AdoptedText/ta97/ EREC1323.htm (accessed on: 27.01.2015).

34 Parliamentary Assembly, Resolution 1248 (2001) European Committee for the Prevention of Torture (CPT): composition, http://www.assembly.coe.int/Main.asp?link=/Documents/ 
Recommendation 1257 (1995) applies to the conditions of detention of persons in prisons in the member states of the Council of Europe ${ }^{35}$. The document underlines the important role of CPT in the protection of the rights and freedoms of individuals detained in detention centers. However, the recommendation does not regulate any rules for the selection of Committee members, but nevertheless constitutes an important document regarding the $\mathrm{CPT}$ function. In subsequent recommendations clarifying the principles for appointing members of the $\mathrm{CPT}$, there are numerous references to it, due to the important issue of linking the CTP function with the relevant competences of its members, which is to ensure the expert nature of the Committee as an international body for controlling human rights.

The Recommendation 1323 (1997) relates to the strengthening of the mechanism of the Convention Against Torture. From the outset it refers to the Recommendation 1257 (1995), reaffirming support for the activities of the CPT performing preventive functions through a system of visits in the countries ${ }^{36}$. It may be noted that the ratification of the ECPT by a growing number of countries from Central and Eastern Europe is a huge challenge for the CPT, which has a major role to play in improving the conditions of detention of persons deprived of liberty in those countries. The recommendation 1323 refers in its provisions also to the composition of the CPT, where special attention is put to professional criteria, gender and age. The aim is to ensure a more balanced composition of the Committee, e.i. increasing the involvement of specialists from the prison service and forensic medicine, as well as increasing the number of women. In the final provisions, the document draws attention to the building of effective cooperation between the CPT and PACE, in particular the Committee on Legal Affairs and Human Rights on the performance of ECPT obligations by the countries.

The Resolution 1248 (2001) directly relates to the recommendation of the Recommendation 1323 (1997), in which the need for a more balanced composition of the CPT is stressed ${ }^{37}$. It was also stressed that there is the need for rapid entry into force of Protocol No. 2 to the Convention against Torture, which provides for new rules for the renewal of the composition of the CPT and the possibility of their re-election. The resolution indicated that the composition of the CPT of that time was not balanced, both from the point of view of women's representation, as well as because of the different professional competences of its members. PACE indicated,

AdoptedText/ta01/ERES1248.htm (accessed on: 24.01.2015).

35 Parliamentary Assembly, Recommendation 1257 (1995) on the conditions of detention in Council of Europe member states ..., op. cit., p. 1.

36 Parliamentary Assembly, Recommendation 1323 (1997) on strengthening the machinery of the European Co- nvention for the Prevention of Torture and Inhuman or Degrading Treatment or Punishment..., op. cit., p. 1.

37 Resolution 1248 (2001) European Committee for the Prevention of Torture (CPT): composition..., op. cit., p. 1. 
Procedure of Appointing Members of the European Committee for the Prevention...

that it is partly responsible for this state of affairs, as well as the composition of national delegations, and it perceives some possibility in this area of exercising a certain control. It notes, however, that in practice the PACE Bureau was not able to examine their own national candidates as members of the CPT. This task belongs to the Committee of Legal Affairs and Human Rights. In view of the above, the PACE asked the National Delegations in the Resolution to check whether the lists of their CPT candidates are compliant with the requirements of Recommendation 1323 (1997). A similar position was also presented to the Committee on Legal Affairs and Human Rights which was obliged to study the listof candidates provided by the national delegations in accordance with the criteria of recommendation $1323^{38}$.

The Resolution 1540 (2007) of PACE is a specific instruction for countries and Sub-Committee on Human Rights of PACE (hereinafter referred to as: Subcommittee). The resolution at the very beginning of its provisions refers to the earlier regulation of the principles of the appointment of CPT members, i.e. Resolution 1248 and Recommendation 1323. It underlines the fact that PACE attaches great importance to the work of the CPT. 39 At the outset of the document, it is noted that the Committee in terms of the effectiveness and efficiency of its activities is conditioned by the moral condition, professional qualifications and personal implications of all its members.

In order to facilitate the selection of suitable candidates for CPT at the national level, the Resolution clarifies the most important issues related to the selection criteria. It indicates the need for equal treatment in terms of gender equality, with a preference for candidates of the under-represented sex in CPT. The list of candidates should include at least one man and one woman, except when all the candidates are the under-represented sex in the CPT (less than 40\%). A list that does not comply with this rule is rejected by the PACE Bureau.

It is also recommended to organize the procedure of national consultation concerning suitable candidates with relevant state bodies and non-governmental organisations (such as ministries of Justice, Interior and Health, prison administration, academic institutions, non-governmental organizations working in the field of combating torture and assistance for prisoners and people in psychiatric institutions). What is also underlined is the important consultative and information role regarding the candidates to be held by the national delegations in the PACE - at the opinion stage by the PACE Bureau. Therefore, the knowledge of representatives of national delegations in PACE on the subject of candidates for CPT is extremely significant.

As an important element of national priority, the resolution indicates conducting interviews with the qualified candidates, in order to make a correct assessment of their qualifications, motivation and availability, as well as language

38 Resolution 1248 (2001) European Committee for the Prevention of Torture (CPT): composition..., op. cit., p. 1 
skills, which can be carried out by an independent panel of experts. Taking into consideration the time-consuming and physically demanding nature of the work in the CPT, candidates should have sufficient predisposition in this regard.

Concerning the status of the independence of the CPT members as a criterion for qualifying candidates, PACE explains in the resolution, that the independence of the CPT members is not disputed by the mere fact that they are government officials or are employed in the public sector. However, if the persons at the central

are responsible for defining the national policy in a given sector and, therefore, they may be responsible for their actions (including political responsibility), they should not be members of the $\mathrm{CPT}^{39}$.

In the case of dual citizenship of the candidate, for the purpose of the ECPT, i.e. the principle of representation in the CPT by a citizen of the state - the ECPT party, the conclusive factor is so-called effective citizenship, i.e. citizenship of the country in which the candidate exercises his or her political rights. In this regard, the Resolution indicates that the Article 4 of the act 3 of $\mathrm{ECPT}^{40}$, which prohibits the presentation of candidates who do not have the nationality of a member state (the party), is obsolete, as people, having dual nationality, must not be automatically disqualified from the contest procedure. In the opinion of the PACE, this should be taken into account and considered by the Committee of Ministers of the Council of Europe in its opinions and creation work concerning the candidates for CPT, even in the context of the cessation of the application of Article 4 of the act 3 of ECPT.

The instructions of the Resolution regarding the principles for the selection of CPT members are also addressed to the Subcommittee on Human Rights, which evaluates candidates. As part of the work of the Subcommittee, activities should be undertaken consisting in inviting the heads of national delegations to list their candidates from their countries. This will enable gaining additional information about the individual candidates, as well as national competition procedures, according which they were selected. An important parallel issue is the obligation for the Subcommittee Chairperson to collect all data on the availability of time, language skills of candidates for CPT, etc.

The Resolution requires rejection of the list of candidates, in particular when there is no relevant information, even if deficiencies do not apply to all the candidates from the list. The rejection should also occur in a situation where not all candidates meet the minimum requirements provided for in ECPT. In addition, another reason for the rejection of the list of candidates may be the lack of fulfilment of the criterion

39 Resolution 1540 (2007) Improving selection procedures for CPT members..., op. cit., p. 1.

40 Article 4 section 3 "No two members of the Committee may be nationals of the same State. European Convention for the Prevention of Torture and Inhuman or Degrading Treatment or Punishment, done in Strasbourg on 26 November 1987 (Dz.U. z 1995, Nr 46, poz. 238) [Journal of Laws of 1995 No. 46 item 238). 
Procedure of Appointing Members of the European Committee for the Prevention...

of balanced representation of both sexes, except for when all the candidates on the list are the under-represented sex in the CPT (less than 40\%).

An important aspect, which is possible in individual cases, is questioning the candidates (so-called improvement of information). This occurs if the Subcommittee decides that the information contained in the candidate's résumé is not sufficient or if the information provided by the chairman of the national delegation prevent valid choice from a list of people reported by the country. Questioning of a candidate may also be the case if the Subcommittee finds that national preselection was insufficiently precise to be able to make a correct indication of the person as the CPT member. When pre-selection procedures at the level of domestic internal proceedings do not raise any objections of the Subcommittee, the preferences of national delegations to the candidate shall be deemed to be the relevant opinion when choosing a member to CPT.

The work of the Subcommittee on Human Rights concerning judging candidates to the CPT ends with the release of recommendations, with a concise justification relating to candidates from the list. The recommendation of the Subcommittee is directed to the PACE Bureau and is the basis for the formulation of its opinion, passed then to the Committee of Ministers of the Council of Europe. Communication between the PACE and the Committee of Ministers is an important element in the international procedure for appointment of the CPT members since it positively determines the selection of highly qualified candidates.

\section{Summary}

The procedure for electing members of the European Committee for the Prevention of Torture and Inhuman or Degrading Treatment or Punishment is significant for several reasons. Although this issue is not the subject of a broad discussion neither in Polish, nor in foreign literature, it appears that it deserves attention, especially for those who claim to perform international functions in the CPT. The national and international procedures for election of members to the Committee should ensure strictly expert composition, uphold their political and professional independence, but most importantly - it must guarantee the personal involvement of candidates in their work. The Council of Europe, as visible for more than 25 years of existence of the CPT, has been also working to meet this challenge, as evidenced by resolutions and recommendations that particularise both the delegating of candidates from countries through the national pre-selection, and their choice in the international procedure by PACE and the Committee of Ministers of the Council of Europe. It should be noted that the CPT compositions from 1989 onwards have been characterized by the high professionalism, which is confirmed by both the standards and the results of the checks carried out in the member 
states during the visits (reports and recommendations). Regulation of the PACE in terms of procedures for selection of the CPT members is yet another significant aspect, it constitutes a better alternative to improve practices and mechanisms (both national and international), and nominates the most qualified candidates for the Committee, without the necessity of changing the content of ECPT. Having regard to the achievements of the Council of Europe in this area, one can only hope that it succeeds.

\section{BIBLIOGRAPHY}

Bisztyga A., Ochrona praw człowieka w systemie Rady Europy, (in:) B. Banaszak, A. Bisztyga (eds.), System ochrony praw człowieka, Kraków 2003

Cassese A., A New Approach to Human Rights: The European Convention for the Prevention of Torture, American Journal of International Law No. 83 (1989)

Filipek B., Kontrola przez Radę Europy wykonywania zobowiązań przyjętych przez państwa członkowskie, Kraków 2007, rozprawa doktorska niepublikowana

Ginther K., The European Convention for the Prevention of Torture and Inhuman or Degrading Treatment or Punishment, European Journal of International Law Vol. 2 No. 123 (1990)

Haug H., Efforts to Eliminate Torture through International Law, The International Review of the Red Cross No. 775 (1989)

Hołda, Europejski Komitet Zapobiegania Torturom (z problematyki instytucji kontrolnych w obszarze Rady Europy), Annales Universitatis Mariae Curie-Sklodowska Vol. XV.2/2008

Kuźniar R., Prawa człowieka. Prawo, instytucje, stosunki międzynarodowe, Warszawa 2004

Łasak K., Warunki dopuszczalności skargi zbiorowej w systemie Europejskiej Karty Społecznej, (in:) Polska i Rada Europy 1990-2005, (ed.) H. Machińska, Warszawa 2005

Michałowska G., Ochrona praw człowieka w Radzie Europy i w Unii Europejskiej, Warszawa 2007 The European Committee for the Prevention of Torture And Inhuman or Degrading Treatment or Punishment, Historical background and main features of the Convention, CPT/Inf. (90) 3, Strasbourg 1990

The European Committee for the Prevention of Torture and Inhuman or Degrading Treatment or Punishment (CPT), CPT standards, CPT/Inf/E (2002) 1 - Rev.2013, Council of Europe, Strasbourg 2013 